\title{
The effect of storage on the yogurt fatty acid profile
}

\author{
Beata Paszczyk*, Joanna Łuczyńska, Magdalena Polak-Śliwińska
}

\author{
University of Warmia and Mazury in Olsztyn, Chair of Commodity Science and Food Analysis, Poland \\ *Corresponding author: E-mail: paszczyk@uwm.edu.pl, Tel.: + 48895233681
}

\section{Abstract}

The presented study analysed whether refrigerated storage time affects the fatty acid profile, the content of conjugated linoleic acid (CLA) and trans isomers of C18:1 and C18:2 acids in yogurts made from goat, sheep and cow milk. On the $21^{\text {st }}$ day of storage, significant decreases $(P<0.05)$ in monounsaturated fatty acids (MUFA) and polyunsaturated fatty acids (PUFA) were observed in in yogurts made from cow milk. In yogurts made from sheep and goat milk, the content of these acids fluctuated during storage. The CLA isomer in fresh yogurts ranged from $3.58 \mathrm{mg} \mathrm{g}^{-1}$ fat in yogurts made from sheep milk to $4.47 \mathrm{mg} \mathrm{g}^{-1}$ fat in yogurts made of cow milk. During storage the content of CLA significantly decreased in cow milk yogurts and significantly increased in goat milk yogurts $(P<0.05)$, while it remained more or less unchanged throughout the entire storage period in sheep milk yogurts.

\section{Key words: fatty acids, CLA, trans C18:1, trans C18:2, cow, goat and sheep yogurts, storage time}

\section{Introduction}

Conjugated linoleic acid (CLA) refers to all possible positional and geometric isomers of linoleic acid that contain conjugated double bonds. The beneficial effects of milk CLA in a diet are mainly attributed to two CLA isomers which include cis9trans 11 and trans10,cis12. According to literature data the cis9,trans 11 CLA isomer constitutes from $75 \%$ to over $90 \%$ of the sum of CLA in the fat of milk and dairy products (Chin et al., 1992; Jiang et al., 1998; Lin et al., 1998; Bauman and Lock, 2006; Koba and Yanagita, 2014). Biomedical studies with animal models have demonstrated a variety of health benefits of CLA, including anticarcinogenic, antiatherogenic and antiobesity influence; the enhancement of the immune system and the antidiabetic effect (Akalln and Tokusoglu, 2003; Kee et al., 2010; Molkentin, 1999; Parodi,
2003; Park, 2009; Aydin, 2005; Yang et al., 2015; Hanuš et al., 2018). Typical concentrations of CLA in milk fat are 3-6 $\mathrm{mg} \mathrm{g}^{-1}$ fat (Kelly et al., 1998). The level of CLA in milk fat mainly depends on the feeding period, as well as lactation period, breed and individual determinants of cows. According to literature data (Kelsey et al., 2003; Żegarska et al., 2006; Zunong et al., 2008; Frelich et al., 2012; Hanuš et al., 2016) higher contents of this fatty acid occur in fat of milk from the summer season and lower contents in milk fat from the winter season. The content of CLA in dairy products (fermented milk or cheeses) may differ from that in milk. The level of CLA in dairy products is significantly affected by conditions occurring during technological processing and by the activity of added starter cultures (Shantha et al., 1995; Jiang et al., 1998; Lin, 2003; Kim and Liu, 2002; Martin and Jenkins, 2002; Sieber et al., 2004; 
Ogawa et al., 2005; Seçkin et al., 2005; Xu et al., 2006; Bzducha and Obiedziński, 2007; Bisig et al., 2007; Prandini et al., 2007; Domagała et al., 2009; Salamon et al., 2009a; Salamon et al., 2009b; Hennessy et al., 2009; Santos Junior et al., 2012; Paszczyk et al., 2016, Yang et al., 2017). Kim and Liu (2002) showed that the CLA content in fermented milk was affected by the type of bacterial strain applied, the viable cell count, the optimal substrate concentration, and the incubation conditions (time and pH). According to Domagała et al. (2009), the type of the applied starter culture and storage time affected CLA contents in cream subjected to fermentation. Shantha et al. (1995) observed an increase in CLA content from $4.40 \mathrm{mg}$ $\mathrm{g}^{-1}$ fat in unprocessed raw milk to $5.25 \mathrm{mg} \mathrm{g}^{-1} \mathrm{fat}$ in a yogurt produced with $0.05 \%$ fat. According to literature data (Florence et al., 2012a, Florence et al., 2012b, Serafeimidou et al., 2012; Serafeimidou et al., 2013) the type of milk and storage time of yogurts can affect the amount of CLA isomers in fermented milks. The content of CLA in the Italian commercial yogurts and fermented milk studied by Prandini et al. (2007) ranged from $4.42 \mathrm{mg} \mathrm{g}^{-1}$ fat (probiotic yoghurts) to $6.15 \mathrm{mg} \mathrm{g}^{-1}$ fat (fermented milks of mountain pasture). Greek full-fat yogurts produced from cow, sheep and goat milk examined by Serafeimidou et al. (2012) contained CLA in

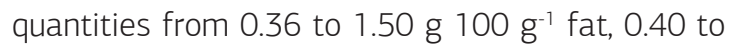

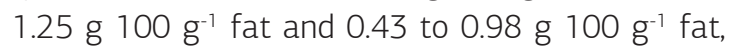
respectively.

In Poland yogurt is among the most popular dairy products. The popularity of yogurt is due to various health claims and therapeutic values. Cow milk is most commonly used for yogurt production, but yogurt from goat and sheep milk is produced as well. Sheep and goat milk are of high nutritional value. The milk of these animals is characterized by a smaller diameter of fat globules than milk of cows and contains more short-chain and polyunsaturated fatty acids (Park et al., 2007). As a result, goat and sheep milk is digested faster than cow milk.

The purpose of the presented study was to determine whether the refrigerated storage time affects the fatty acid profile, including the content of cis9trans 11 C18:2 (CLA) acid and trans isomers of C18:1 and C18:2 acid in yogurts made from goat, sheep and cow milk.

\section{Materials and methods}

\section{Experimental material}

Raw cow, goat and sheep milk were obtained from individual farms located in the Warmia and Mazury voivodeship. The yogurts were produced with the thermostat method according to the following technological scheme: goat, sheep and cow raw milk were heated to a temperature of $45^{\circ} \mathrm{C}$ and were then centrifuged and degassed $(80 \mathrm{kPa}$; $\left.60^{\circ} \mathrm{C}\right)$, subjected to HTST pasteurization $\left(72^{\circ} \mathrm{C} / 15\right.$ s) (pasteurizer ALFA-LAWAL P20-HB, Sweden) and cooled to $6^{\circ} \mathrm{C}$. Afterwards, the milk was standardized to a fat content of $2 \pm 0,1 \%$ by the addition of skimmed milk. The standardized milk was then subjected to a two-stage homogenization (18/5 MPa, temperature $65^{\circ} \mathrm{C}$ ) (homogenizer CNO03, Spomasz Bełżyce, Poland) and a long-term VHT pasteurization $\left(90^{\circ} \mathrm{C} / 5 \mathrm{~min}\right)$ (pasteurizer ALFA-LAWAL P20$\mathrm{HB}$, Sweden). After cooling to the temperature of $45^{\circ} \mathrm{C}$, the milks were inoculated with starter culture Chr. Hansen F-DVS YoFlex ${ }^{\oplus}$ Premium 2.0 DVS (Chr. Hansen, Denmark), containing Streptococcus thermophilus and Lactobacillus delbrueckii subsp. bulgaricus. The prepared culture (pre-incubated for 2 hours at $45^{\circ} \mathrm{C}$ ) was added in the amount of $1 \mathrm{~mL}$ per 1 litlre of milk. The yogurts were transferred to unitary packages and left to ripen in thermostats (Binder GF115 Tuttingen, Germany) at a temperature of $43.5^{\circ} \mathrm{C}$ until they reached $\mathrm{pH}$ 4.6.

For every type of milk, two production processes were carried out. Each time, two samples of yogurts from each batch were collected for analyses. All determinations were conducted in two parallel replications.

Analyses were carried out for freshly-produced yogurts (marked in table and figures as samples 0 ) and yogurts that were cool stored at $8 \pm 1{ }^{\circ} \mathrm{C}$ for 21 days (analysed in $7^{\text {th }}, 14^{\text {th }}$ and $21^{\text {st }}$ day of storage).

\section{Analytical methods}

\section{Lipid extraction}

The milk fat was extracted according to the Folch's method (Folch et al., 1957). 
Preparation of fatty acid methyl esters

Fatty acid methyl esters were prepared according to IDF method using a methanolic solution of KOH (ISO 15884:2002).

\section{Gas chromatography (GC) analysis}

The composition of fatty acids was determined by gas chromatography (Hewlett Packard 6890 GC System (Münster, Germany) with a flame ionization detector (FID), in $100 \mathrm{~m}$ capillary column (produced by Chrompack, Middelburg, the Netherlands) with CP Sil 88 phase. The column diameter was $0.25 \mathrm{~mm}$, the film was $0.20 \mu \mathrm{m}$ thick. The determinations were carried out in the following conditions: column temperature from $60^{\circ} \mathrm{C}$ (for $1 \mathrm{~min}$ ) to $180^{\circ} \mathrm{C}, \Delta \mathrm{t}=5^{\circ} \mathrm{C} /$ min, detector temperature $250{ }^{\circ} \mathrm{C}$, injector temperature $225^{\circ} \mathrm{C}$, carrier gas helium, gas flow $1.5 \mathrm{~mL} /$ min. Sample injection volume was $0.4 \mu \mathrm{L}$ (split: 50:1). Identification of fatty acids was carried out based on the comparison of their retention time with the retention time of methyl esters of fatty acids of the reference milk fat (BCR Reference Materials) of CRM 164 symbol. The positional trans isomers of C18:1 were identified using the standards of methyl esters of these isomers (trans6, Supelco and trans9 and trans 11 , Sigma-Aldrich), whereas the trans isomers of C18:2 acid (cis,trans and trans,cis) were identified with the use of a mixture of standards of C18:2 isomers (Supelco). The cis9trans 11 CLA isomer was identified using a mixture of CLA methyl esters (Sigma-Aldrich).

Contents of fatty acids were calculated in $\mathrm{mg}$ $\mathrm{g}^{-1}$ fat in respect of the introduced standard (methyl ester of (21:0 acid).

\section{Statistical analysis}

The statistical analysis was carried out using STATISTICA ver.13.1 software. To calculate the significance of differences one-way analysis of variance (ANOVA) was used at a significance level of $a=0.05$. Differences between mean values were evaluated with the Duncan's test.

\section{Results and discussion}

\section{Fatty acid composition of yogurt}

Table 1 shows the fatty acid composition of the yogurts in $\mathrm{mg} \mathrm{g}^{-1}$ fat during a 21-day storage period at $8{ }^{\circ} \mathrm{C}$. In all analysed yogurts, fresh and stored, saturated fatty acids (SFA) were dominant. Sheep milk yogurts were characterized by a higher content of PUFA than yogurts made of cow and goat milk. The content of MUFA in all analysed products was at a similar level. Changes were observed in the content of each group of fatty acids during the storage time of yogurts. In yogurts from goat milk, the content of SFA significantly increased $(P<0.05)$ on the $7^{\text {th }}$ day of storage and stayed at a similar level till the $21^{\text {st }}$ day of storage. In yogurts made of sheep and cow milk, the content of SFA varied. A significant decrease $(P<0.05)$ in the content of those acids was found in $21^{\text {st }}$ day of storage (Table 1). The conduced analysis showed a significant decrease $(P<0.05)$ of the content of MUFA and PUFA in yogurts made of cow milk on the $21^{\text {st }}$ day of storage. The contents of PUFA in yogurts made from goat milk significantly increased on the $7^{\text {th }}$ day of storage and remained stable until the $21^{\text {st }}$ day of storage. The content of PUFA in yogurts made from sheep milk fluctuated in the time of storage and there was a significant increase $(P<0.05)$ in the content of MUFA on the $7^{\text {th }}$ day of storage. The contents of short-chain fatty acids (SCFA), important from a nutritional point of view, also fluctuated during the storage period. These acids have a number of important biological functions such as regulation of cholesterol and triglyceride synthesis in liver cells and have a therapeutic effect on the colon epithelium and play an important role in prevention, as well as in the treatment of breast, colon and liver cancer (mainly butyric acid) (Przybojewska and Rafalski, 2003; Kuczyńska et al., 2011; GómezCortés et al., 2018; Hanuš et al., 2018).

The highest contents of SCFA were found in yogurts made of goat milk. Yogurts made of cow milk were characterized by the lowest content of SCFA (Table 1). A significant increase $(P<0.05)$ in the content of SCFA was found in yogurts made of goat 


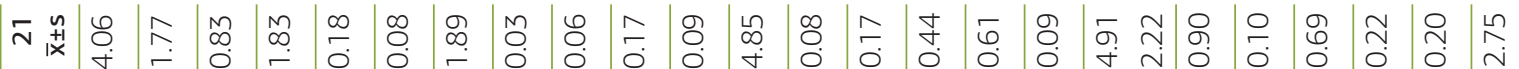

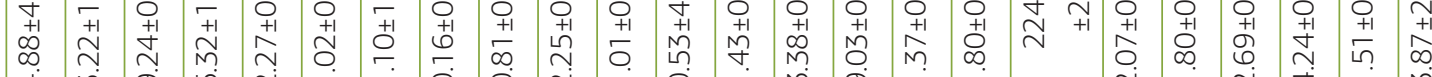
‡

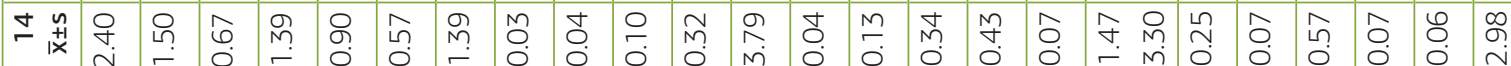

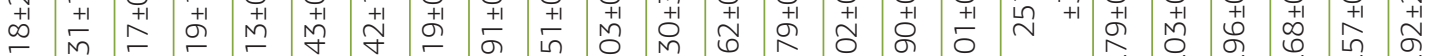

亚

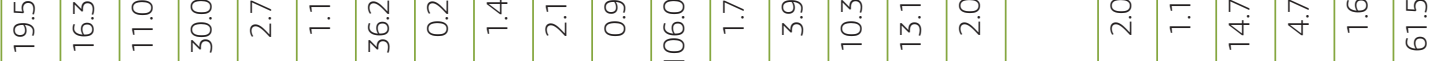

○

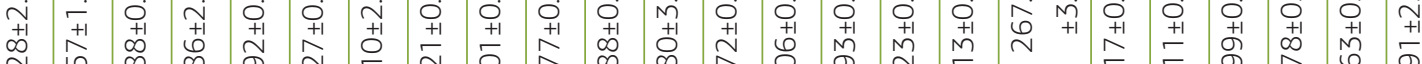

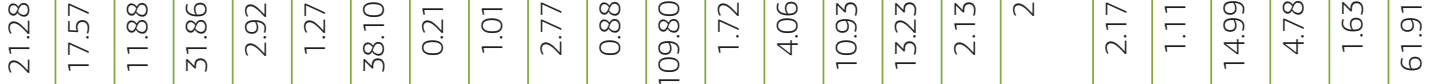

స

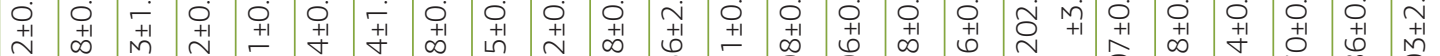

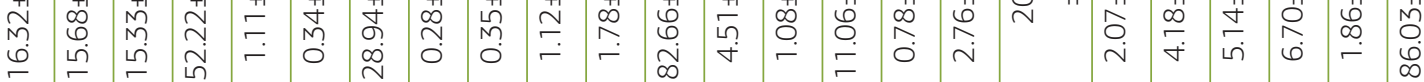

- 荿

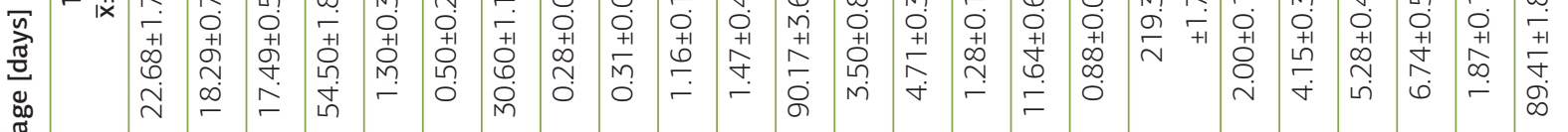

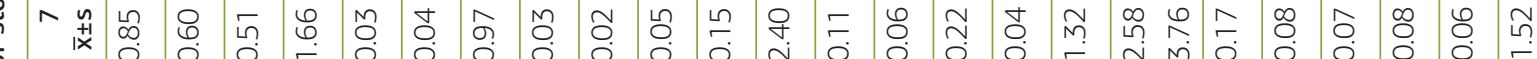

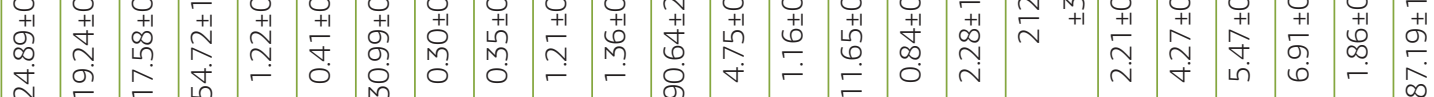

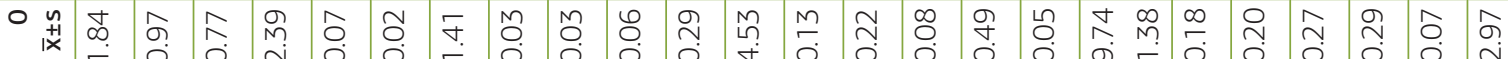

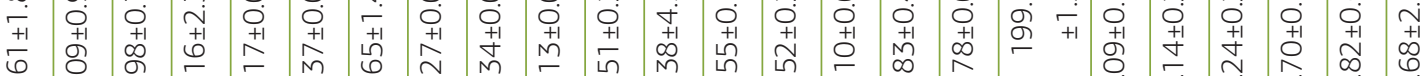

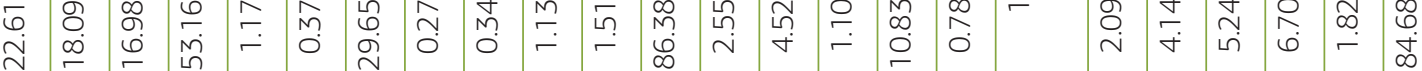

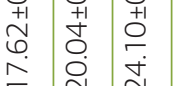

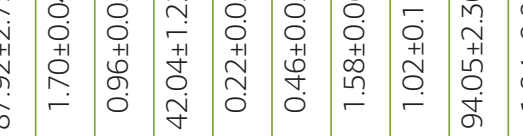

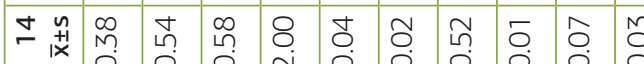

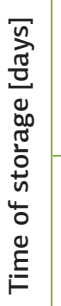

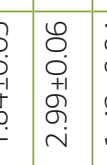

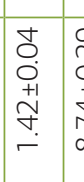

กิ

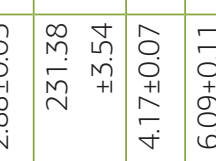

$$
\begin{aligned}
& \text { Е }
\end{aligned}
$$

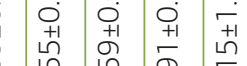

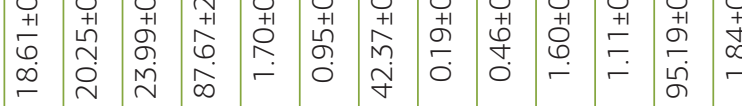




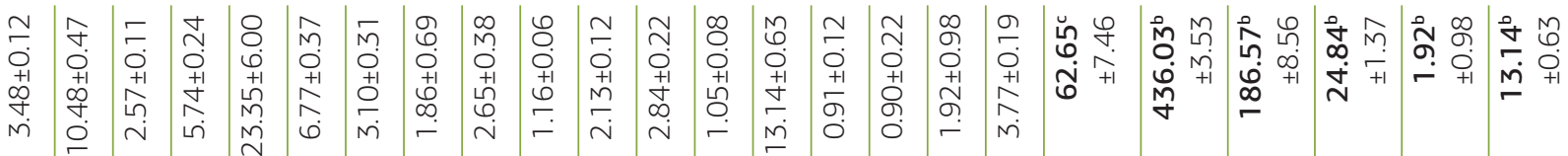

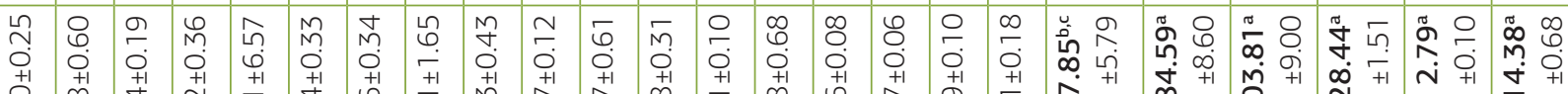

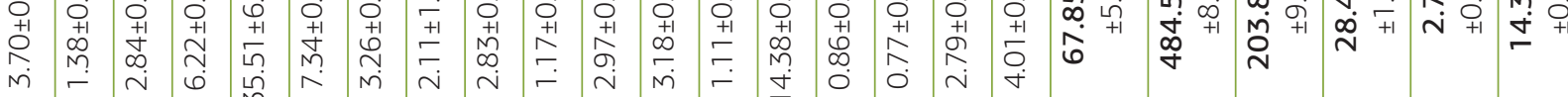

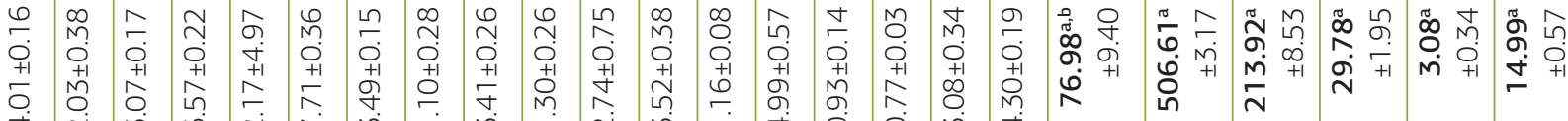

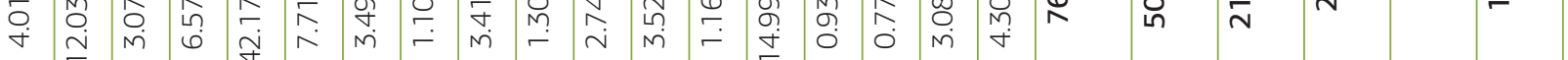

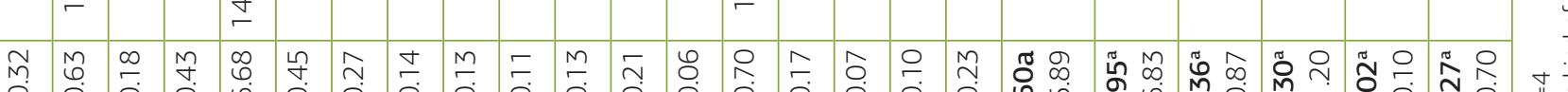

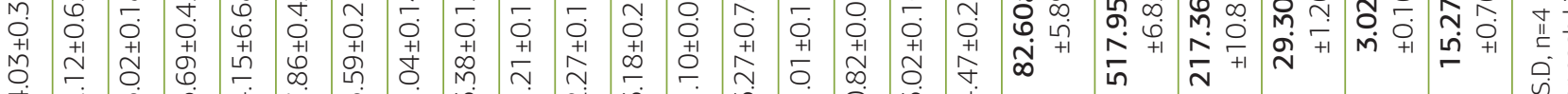

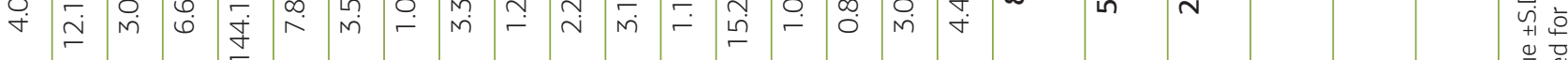

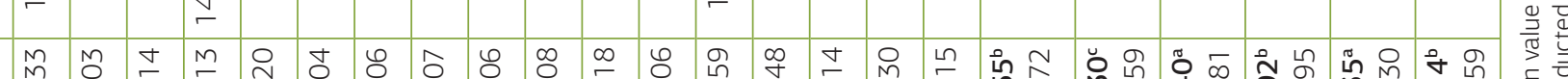

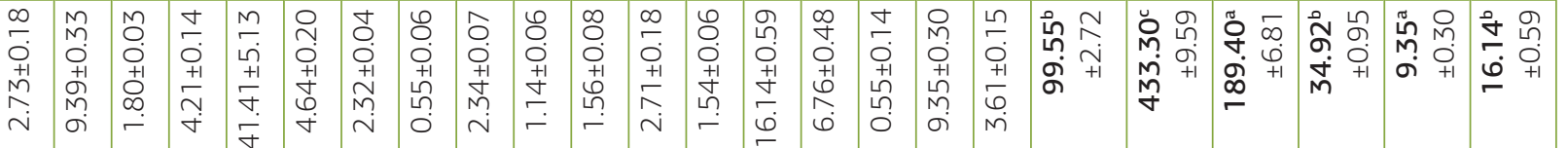

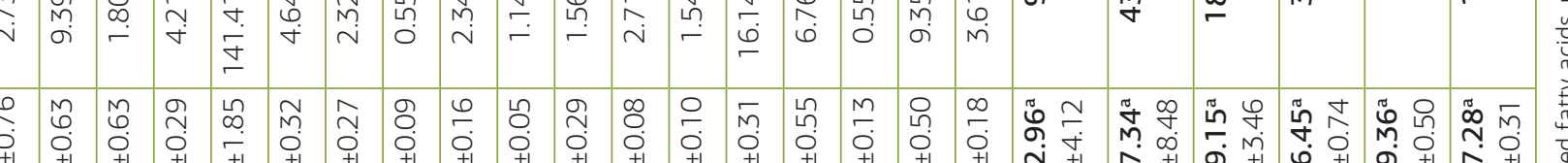
$\stackrel{\frac{n}{n}}{\stackrel{2}{2}}$

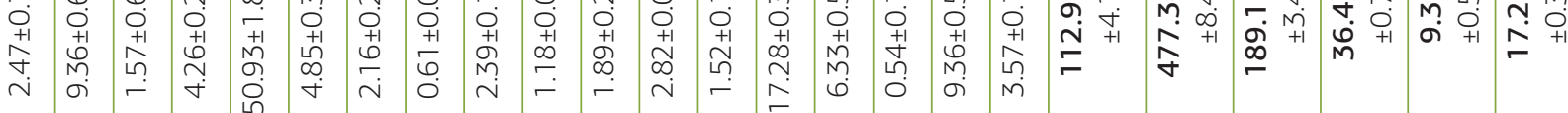
는

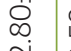


milk, the opposite tendency was found in yogurts made of sheep and cow milk. Changes in the content of each group of fatty acids in the stored yogurts made of goat and cow milk were also found by Serafeimidou et al. (2013).

The data presented in Table 1 shows that analysed yogurts were characterized by a diverse content of n-3 PUFA and n-6 PUFA. The highest content of n-3 polyunsaturated fatty acids was found in yogurts made of sheep milk. Yogurts made of goat milk were characterized by the lowest content of those fatty acids. $n-6$ polyunsaturated fatty acids in the analysed products were on similar levels (Table 1). n-3 and n-6 polyunsaturated fatty acids have shown many health benefits for humans (Connor, 2000; Williams, 2000; Wahrburg, 2004; Sokoła-Wysoczańska et al., 2018). Since n-3 and n-6 polyunsaturated fatty acids are essential nutrients that cannot be synthesized in the body and must be obtained from the diet, it is important that these acids remain stable or increase during storage conditions to provide their beneficial effects. The content of n-3 and n-6 polyunsaturated fatty acids significantly increased $(P<0.05)$ in goat milk yogurts during storage. The opposite tendency was observed in cow milk yogurts (Table 1). In yogurts made of sheep milk, $n-3$ polyunsaturated fatty acids remained at a constant level throughout the entire storage period and the content of n-6 polyunsaturated fatty acids fluctuated. The increase in the content of $n-3$ and $n-6$ polyunsaturated fatty acids in goat yoghurts may suggest that they did not undergo oxidation reactions that would lead to a reduction of these acids and therefore result in a loss of nutritional and sensory value of yogurt. This may be due to the better antioxidant properties of goat milk proteins (Khan et al., 2019). Goat milk differs slightly from cow and sheep milk by its basic chemical composition, protein structure. Casein and whey proteins are the main group of milk proteins found in different ratios in milk of various species of ruminants. Casein micelles in goat, sheep and cow milk differ in structure, composition and size. The proportions of individual protein fractions in those milks are also varied (Rafiq et al., 2016).

\section{CLA (cis9trans11 C18:2) content in samples}

The conducted analyses demonstrated differences in CLA content in fresh yogurts and in yogurts analysed after various prolonged times of storage (Figure 1, Figure 2 and Figure 3).

In fresh yogurts made from goat milk the CLA content was $3.83 \mathrm{mg} \mathrm{g}^{-1}$ fat. Significantly higher CLA contents were found in yogurts analysed on the $7^{\text {th }}$ and $14^{\text {th }}$ and $21^{\text {st }}$ days of storage (Figure 1). In fresh and stored yogurts made from sheep milk, the content of CLA was at the same level (Figure 2). In fresh yogurts made of cow milk the CLA content was $4.47 \mathrm{mg} \mathrm{g-}^{-1}$ fat. Lower CLA contents (4.30 $\mathrm{mg} \mathrm{g}^{-1}$ fat and $4.01 \mathrm{mg} \mathrm{g}^{-1}$ fat and $3.77 \mathrm{mg} \mathrm{g}^{-1} \mathrm{fat}$ ) were found in yogurts analysed on the $7^{\text {th }}$ and $14^{\text {th }}$ and $21^{\text {st }}$ days of storage, respectively (Figure 3 ).

Milk of mammals has a high nutritional value; however, small differences in the composition of the different types of milk may generate differences in the nutritional value and different technological usability of said milk as well as different quality of dairy products made from it (Park et al., 2007; Barłowska et al. 2011). The proportion of individual fatty acids in milk fat can vary during milk processing, for example, the method of milk treatment (e.g. pasteurization) and storage influence the proportion of CLA isomers and other fatty acids content in milk and dairy products (Herzallah et al. 2005; Santos Junior et al., 2012; Yue et al., 2016; Khan et al., 2017). Often, this is not a direct change in the proportion of fatty acids but rather it is a change in the molecular fatty acids configuration, resulting in variations in the proportion of fatty acid isomers (Pecová et al., 2019).

It is likely that the starter culture used for making yogurts could show a significant improvement in cis9trans 11 CLA level, thereby increasing its CLA content during storage. On the other hand, decrease of CLA in some dairy products, perhaps due to oxidative reactions, that cause damage to the conjugated system of double bonds, thus inducing a decrease in CLA content in stored products (Shantha et al., 1995). According to literature data (Yang et al., 2000), owing to the presence of conjugated unsaturated bonds, the CLA is more susceptible to processes of oxidation and isomerization than linoleic acid.

Whether the type of the applied starter culture and storage time has an influence on the CLA con- 
tent of dairy products, is still a matter of discussion. Shantha et al. (1995) demonstrated that no changes occurred in the CLA content in yogurt or other dairy products when stored at $4{ }^{\circ} \mathrm{C}$ for 6 weeks. Changes in CLA content in yogurts produced from cow milk and sheep milk stored for 14 days at $5{ }^{\circ} \mathrm{C}$ were demonstrated by Serafeimidou et al. (2013). According to Serafeimidou et al. (2013) the content of CLA in yoghurts made of cow milk after 7 days of storage at $5{ }^{\circ} \mathrm{C}$ was higher (4.5 $\mathrm{mg} \mathrm{g}^{-1}$ fat) than the yogurts analyzed on day 1 (4.1 $\mathrm{mg} \mathrm{g}^{-1}$ fat). A significantly lower content (2.4 $\mathrm{mg} \mathrm{g}^{-1}$ fat) of this fatty acid was found by these authors in yogurts analysed after 14 days of storage. The previous' research has shown that of the three applied starter cultures: Ceska-star Y508 (contained Lactobacillus delbrueckii subsp. bulgaricus and Streptococcus thermophiles), YC-X11 (contained Lactobacillus delbrueckii subsp. bulgaricus and Streptococcus thermophiles) and ABT-1 (contained Streptococcus thermophilus, Lactobacillus acidophilus and Bifidobacterium bifidum) only the Ceska-star Y508 culture caused a significant increase in CLA content in the stored fermented milk drinks. The mean content of CLA in fresh drinks reached $3.60 \mathrm{mg} \mathrm{g}^{-1}$ fat. Significantly higher CLA contents (3.85 and $3.89 \mathrm{mg} \mathrm{g}^{-1}$ fat) were found in drinks after 6 and 13 days of storage, respectively (Paszczyk et al., 2016). Changes in the CLA content in ecological and conventional fermented milk stored for 7 days at $4{ }^{\circ} \mathrm{C}$ were also reported by Florence et al. (2012a). According to their research, organic and conventional milk produced with Streptococcus thermophilus and Lactobacillus bulgaricus TAO4O LB340 on the $7^{\text {th }}$ day of storage had a significantly lower content of CLA than milk tested on the first day of storage. A fermented milk made of organic milk produced with Streptococcus thermophilus and Lactobacillus bulgaricus TA040 LB340 and Bifidobacterium animalis subsp. lactis HN019 was also characterized by significantly lower levels of CLA when tested on the $7^{\text {th }}$ day of storage compared to testing on the first day. In conventional fermented milk produced with the same bacterial strains, no significant changes in CLA content during refrigerated storage were observed. Domagała et al. (2009) determined the effect of six different starter cultures (CHN-19, Flora Danica, YC-180, YC180+Prop., ABY-2 and Danisco Cheese) on the level of conjugated linoleic acid in fermented cream stored for 2, 7 and 14 days. The study of these authors showed that only the addition of culture ABY2 caused an increase in CLA content in the finished product stored for 7 days. Paszczyk and Brandt (2016) showed that the storage of kefirs at $8{ }^{\circ} \mathrm{C}$ for 21 days resulted in a significant decrease in the content of cis9trans11 C18:2 acids in kefirs.

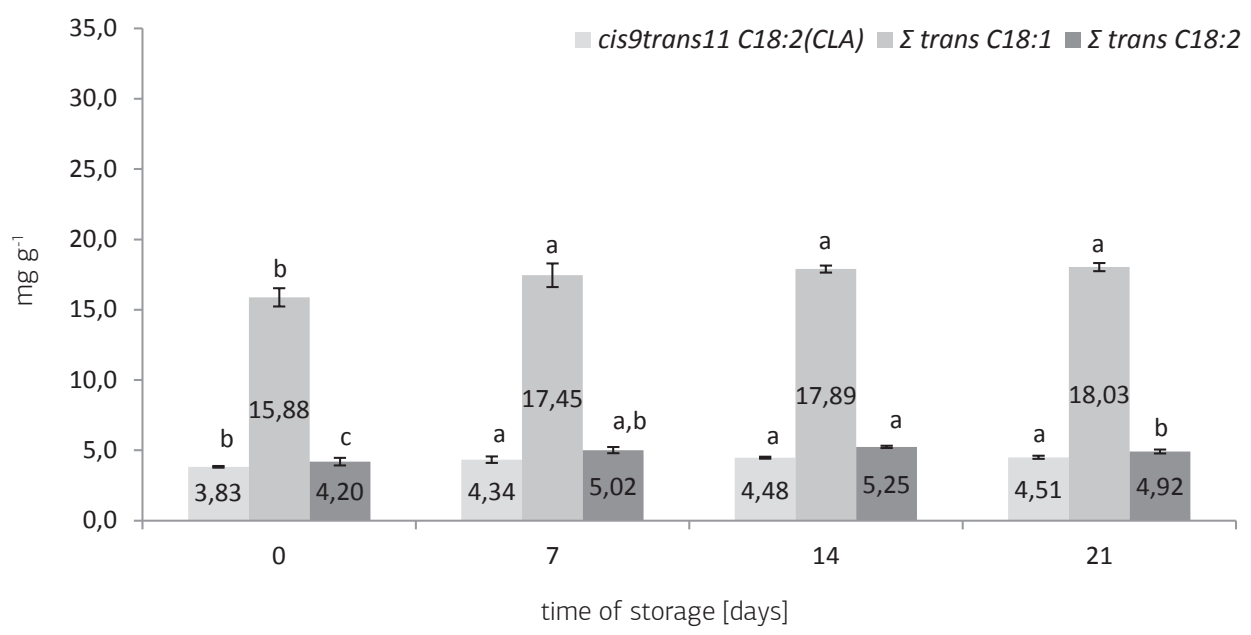

a,b,c - values denoted by different letters indicate statistically significant differences in the content of CLA and other trans isomers during the storage of yogurts $(\mathrm{P}<0.05)$

FIGURE 1. The content of CLA and total C18:1 and C18:2 trans isomers in stored yogurts made from goat milk [mg g-1 fat] 


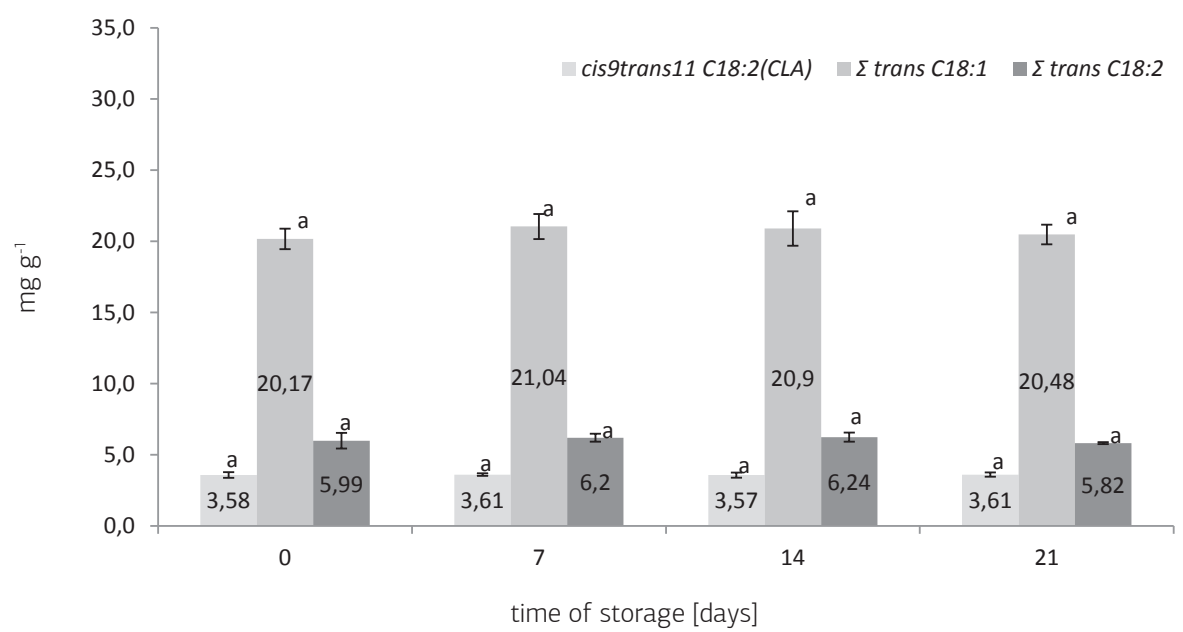

a,b - values denoted by different letters indicate statistically significant differences in the content of CLA and other trans isomers during the storage of yogurts $(\mathrm{P}<0.05)$

FIGURE 2. The content of CLA and total C18:1 and C18:2 trans isomers in stored yogurts made from sheep milk [mg g ${ }^{-1} \mathrm{fat}$ ]

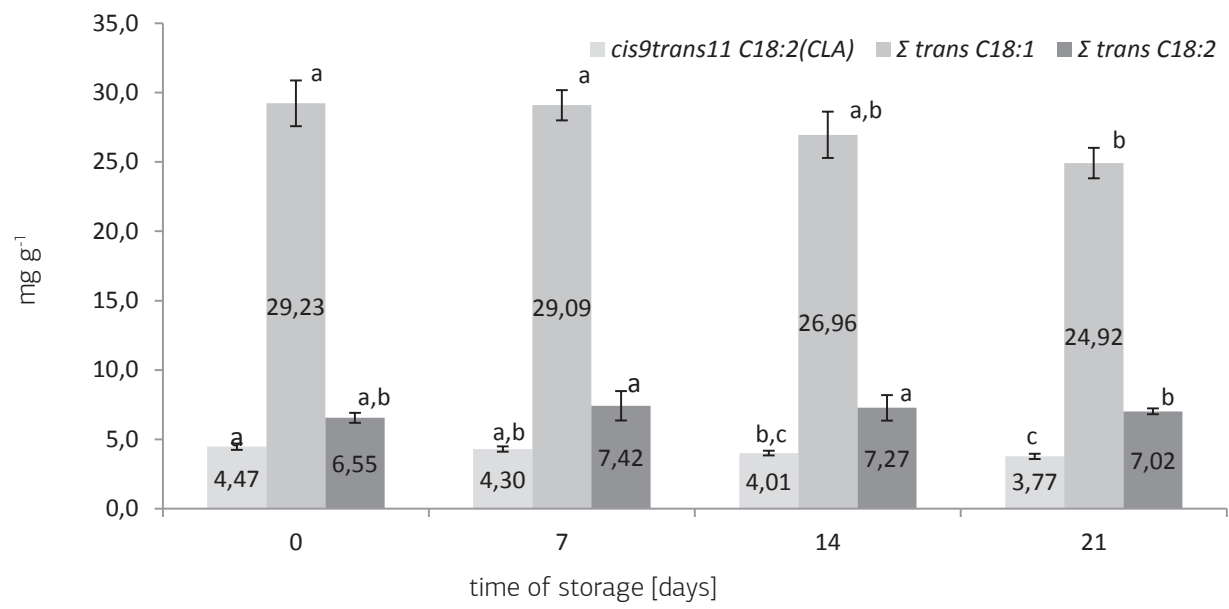

a,b,c - values denoted by different letters indicate statistically significant differences in the content of CLA and other trans isomers during the storage of yogurts $(\mathrm{P}<0.05)$

FIGURE 3. The content of CLA and total C18:1 and C18:2 trans isomers in stored yogurts made from cow milk [mg g $\mathrm{g}^{-1}$ fat]

Trans C18:1 and trans C18:2 content in samples

The total content of trans isomers of C18:1 acid and trans isomers of C18:2 acid in the analysed yogurts made from goat, sheep and cow milk were also subjected to changes (Figure 1, Figure 2 and Figure 3). In yogurts made from goat milk, the lowest contents of trans C18:1 isomers were found in fresh products. Significantly higher $(\mathrm{P}<0.05)$ contents of these isomers were found in yogurts analysed on the $7^{\text {th }}, 14^{\text {th }}$ and $21^{\text {th }}$ days of storage (Fig- ure 1). In yogurts made from sheep milk, both fresh and stored, the content of trans C18:1 isomers was at the same level (Figure 2). For yogurts made from cow milk, the highest content of total trans C18:1 isomers was found in fresh yogurts. A significantly lower $(P<0.05)$ content of these isomers was found in yogurts analysed on the $14^{\text {th }}$ day of storage. Further storage affected a decrease in the content of these isomers in the analysed yogurts (Figure 3). According to a study by Florence et al. (2012), the content of trans C18:1 isomers in organic fermented milks stored at $4{ }^{\circ} \mathrm{C}$ for 7 days was sta- 
ble. The content of these isomers in conventional fermented milk analysed by those authors changed more. Previous studies have shown that the type of the applied starter culture and storage time affect the content of trans C18:1 isomers in fermented milk beverages. A significant increase was found in the fermented milk beverages produced with Ceska-star Y508 and fermented milk beverages produced with ABT-1 starter culture analysed after six days of storage (Paszczyk et al., 2016).

The total content of trans isomers of C18:2 acid changed in the analysed stored yogurt made from goat milk and these changes were statistically significant $(P<0.05)$ (Figure 1$)$. In yogurts made from cow milk analysed on the $7^{\text {th }}$ and $14^{\text {th }}$ days of storage, the total content of trans isomers of $\mathrm{C} 18: 2$ was significantly higher than the content of those isomers in fresh yogurts and yogurts analysed on the $21^{\text {st }}$ day of storage (Figure 3). No statistically significant changes were observed in sheep milk yogurts (Figure 2).

\section{Conclusions}

The study demonstrated that storage of yogurts made from goat, sheep and cow milk at $8 \pm 1^{\circ} \mathrm{C}$ for 21 days causes changes in the fatty acid profile, the content of cis9trans 11 C18:2 (CLA) and trans C18:1 and C18:2 isomers. In all stored yogurts, changes in SCFA, SFA, MUFA and PUFA fatty acids were observed. Storage resulted in a significant decrease of CLA and trans C18:1 isomers in cow milk yogurts and a significant increase in the content of those isomers in goat milk yogurts $(P<0.05)$. In yogurts made from sheep milk, the content of CLA and other marked trans isomers did not change significantly. The study demonstrated that thetype of milk used to produce yogurts plays an important role in the change of fatty acids during refrigerated storage. Given the beneficial role of CLA and other fatty acids for human health and for better evaluation of the nutritional value of storage dairy products, further research is needed to characterize the factors affecting the changes in the content of these functional fatty acids during storage.

\section{Acknowledgements}

The study was financed by the Statutory Theme No. 17.610.008-300. We would like to express special thanks to Waldemar Brandt from the Department of Dairy Science and Quality Management for help in preparing yogurts for research.

\section{Utjecaj skladištenja na profil masnih kiselina jogurta}

\section{Sažetak}

U ovom istraživanju je ispitivan utjecaj hladnog skladištenja na profil masnih kiselina, sadržaj konjugirane linolne kiseline (CLA) te trans izomera masnih kiselina C18:1 i C18:2 u jogurtima od kravljeg, kozjeg i ovčjeg mlijeka. Na 21. dan skladištenja utvrđen je značajan pad $(P<0,05)$ sadržaja jednostruko (MUFA) i višestruko nezasićenih (PUFA) masnih kiselina u jogurtima od kravljeg mlijeka. Sadržaj ovih masnih kiselina mijenjao se u jogurtima od ovčjeg i kozjeg mlijeka. Sadržaj izomera CLA u svježe pripremljenim jogurtima kretao se između 3,58 $\mathrm{mg} \mathrm{g}^{-1}$ masti (ovčji jogurt) i 4,47 $\mathrm{mg} \mathrm{g}^{-1}$ masti (kravlji jogurt). Tijekom perioda skladištenja se sadržaj CLA značajno snizio u kravljem jogurtu, dok je značajno narastao u kozjem jogurtu $(\mathrm{P}<0.05)$, a u ovčjem jogurtu je ostao više manje nepromijenjen.

\section{Ključne riječi: masne kiseline, CLA, trans C18:1, trans C18:2, kravlji, kozji i ovčji jogurt, razdoblje skladištenja}


1. Akalln, A.S., Tokusoglu, Ö. (2003): A potential Anticarcinogenic agent: Conjugated linoleic acid (CLA). Pakistan Journal of Nutrition 2 (2), 109-110. https://doi.org/10.3923/pjn.2003.109.110

2. Aydin, R. (2005): Conjugated linoleic acid: structure, sources and biological properties. Turkish Journal of Veterinary and Animal Sciences 29, 189-195.

3. Bauman, D.E, Lock, A.L. (2006): Conjugated linoleic acid: Biosynthesis and nutritional significance. In: Fox PF, McSweeney PLH, editors. Advanced Dairy Chemistry Volume 2: Lipids: Springer, New York. https://doi.org/10.1007/0-387-28813-9_3

4. Barłowska, J., Szwajkowska, M., Litwińczuk, Z., Król, J. (2011): Nutritional value and technological suitability of milk from various animal species used for dairy production. Comprehensive Reviews in Food Science and Food Safety 10, 291-302. https://doi.org/10.1111/j.1541-4337.2011.00163.x

5. Bisig, W., Eberhard, P., Collomb, M., Rehberger, B. (2007): Influence of processing on the fatty acid composition and the content of conjugated linoleic acid in organic and conventional dairy products - a review. Lait 87, 1-19. https://doi.org/10.1051/lait:2007001

6. Bzducha, A., Obiedziński, M. (2007): Influence of two probiotic Lactobacillus strains on CLA content in model ripening cheeses. Polish Journal of Food and Nutrition Sciences 574 (A), 65-69.

7. Chin, S.F., Liu, W., Storkson, J.M., Ha, Y.L., Pariza, M.W. (1992): Dietary sources of conjugated dienoic isomers of linoleic acid, a newly recognized class of anticarcinogens. Journal of Food Composition and Analysis 5, 185-197. https://doi.org/10.1016/0889-1575(92)90037-k

8. Connor, W.E. (2000): Importance of $n-3$ fatty acids in health and disease. The American Journal of Clinical Nutrition 71 (suppl.), 171S-175S. https://doi.org/10.1093/ajcn/71.1.171s

9. Domagała, J., Sady, M., Najgebauer-Lejko, D., Czernicka, M., Wieteska, I. (2009): The content of conjugated linoleic acid (CLA) in cream fermented using different starter cultures. Biotechnology in Animal Husbandry 25 (5-6), 745-751.

10. Florence, A.C.R, Béal, C., Silva, R.C., Bogsan, C.S.B., Pilleggi, A.L.O.S., Gioielli, L.A., Oliveira, M.N. (2012a): Fatty acid profile, trans-octadecenoic, a-linolenic and conjugated linoleic acid contents differing in certified organic and conventional probiotic fermented milks. Food Chemistry 135, 2207-2214. https://doi.org/10.1016/j.foodchem.2012.07.026

11. Florence, A.C.R, Oliviera, R.P.S., Silva, R.C., Soares, F.A.S.M., Gioielli, L.A., Oliveira, M.N. (2012b): Organic milk improves Bifidobacterium lactis counts and bioactive fatty acids contents in fermented milk. LWT- Food Science and Technology 49, 89-95. https://doi.org/10.1016/j.lwt.2012.04.023

12. Folch, J., Lees, M., Sloane Stanley, G.H. (1957): A simple method for the isolation and purification of total lipides from animal tissues. Journal of Biological Chemistry 226, 497-502.
13. Frelich, J., Šlachta, M., Hanuš, O., Špička, J., Samková, E., Węglarz, A., Zapletal, P. (2012): Seasonal variation in fatty acid composition of cow milk in relation to the feeding system. Animal Science Papers and Reports 30 (3), 219-229. https://doi.org/10.17221/226/2009-cjas

14. Gómez-Cortés, P., Juárez, M., Angel de la Fuente, M. (2018): Milk fat acids and potential health benefits: An update vision. Trends in Food Science \& Technology 81, 1-9. https://doi.org/10.1016/j.tifs.2018.08.014

15. Hanuš, O., Križová, L., Samková, E., Špička, J., Kučera, J., Klimešová, M., Roubal, P., Jedelská, R. (2016): The effect of cattle bread, season and type of diet on the fatty acid profile of raw milk. Archives Animal Breeding 59, 373-380. https://doi.org/10.5194/aab-59-373-2016

16. Hanuš, O., Samková, E., Krížová, L., Hasoňová, L., Kala, R. (2018): Role of fatty acids in milk fat and the influence of selected factors on their variability - A Review. Molecules 23, 1-32. https://doi.org/10.3390/molecules23071636

17. Hennessy, A.A., Ross, R.P., Devery, R., Stanton, C. (2009): Optimization of a reconstituted skim milk based medium for enhanced CLA production by bifidobacteria. Journal of Applied Microbiology 106, 1315-1327. https://doi.org/10.1111/j.1365-2672.2008.04098.x

18. Herzallah, S.M., Al-Ismail, K.M., Humeid M.A. (2005): Influence of some heating and processing methods on fatty acid profile of milk and other dairy products. Journal of Food, Agriculture \& Environment, 3(1), 103-107.

19. ISO 15884:2002 (IDF 182:2002), Milkfat: Preparation of fatty acid methyl esters.

20. Jiang, J., Björck, L., Fondèn, R. (1998): Production of conjugated linoleic acid by dairy starter cultures. Journal of Applied Microbiology 85, 95-102. https://doi.org/10.1046/j.1365-2672.1998.00481.x

21. Kee, J-I., Ganesan, P., Kwak, H-S. (2010): Bioactive conjugated linoleic acid (CLA) in milk. Korean Journal for Food Science of Animal Resources 30 (6), 879-885. https://doi.org/10.5851/kosfa.2010.30.6.879

22. Kelly, M.L., Berry, J.R., Dwyer, D.A., Griinari, J.M., Chouinard, P.Y., Van Ambburgh, M.E., Bauman, D.E. (1998): Dietary fatty acid sources affect conjugated linoleic acid concentrations in milk from lactating dairy cows. Journal of Nutrition 128 , 881-885. https://doi.org/10.1093/jn/128.5.881

23. Kelsey, J.A., Corl, B.A., Collier, R.J., Bauman, D.E. (2003): The effect of breed, parity, and stage of lactation on conjugated linoleic acid (CLA) in milk fat from dairy cows. Journal of Dairy Science 86, 2588-2597. https://doi.org/10.3168/jds.s0022-0302(03)73854-5

24. Khan, I.T., Nadeem, M., Imran, M., Ayaz, M., Ajmal, M., Ellahi, M.Y., Khalique A. (2017): Antioxidant capacity and fatty acids characterization of heat treated cow and buffalo milk. Lipids in Health and Disease 16:163. https://doi.org/10.1186/s12944-017-0553-z

25. Khan, I.T., Nadeem, M., Imran, M., Ullah, R., Ajmal, M., Jaspal M.H. (2019): Antioxidant properties of milk and dairy products: a comprehensive review of the current knowledge. Lipids in Health and Disease 18, 41. https://doi.org/10.1186/s12944-019-0969-8 
26. Kim, Y.J., Liu, R.H. (2002): Increase of conjugated linoleic acid content in milk by fermentation with lactic acid bacteria. Journal of Food Science 67 (5), 1731-1737. https://doi.org/10.1111/j.1365-2621.2002.tb08714.x

27. Koba, K., Yanagita, T. (2014): Health benefitd of conjugated linoleic acid (CLA). Obesity Research \& Clinical Practice 8, e526-e532.

https://doi.org/10.1016/j.orcp.2013.10.001

28. Kuczyńska, B., Wasilewska, A., Biczysko, M., Banasiewicz, T., Drews, M. (2011): Short chaih fatty acids - mechanisms of action, potential clinical indications and nutritional indications. Nowiny Lekarskie 80 (4), 299-304.

29. Lin, H., Boylston, T.D., Luedecke, L.O., Shultz, T.D. (1998): Factors affecting the conjugated linoleic acid content of Cheddar cheese. Journal of Agricultural and Food Chemistry 46 (3), 801-807. https://doi.org/10.1021/jf970639v

30. Lin, T.Y. (2003): Influence of lactic cultures, linoleic acid and fructo-oligosaccharides on conjugated linoleic acid concentration in non-fat set jogurt. Australian Journal of Dairy Technology 58 (1), 11-14.

31. Martin, S.A., Jenkins, T.C. (2002): Factors affecting conjugated linoleic acid and trans- $C_{18: 1}$ fatty acid production by mixed ruminal bacteria. Journal of Animal Sciences 80, 3347-3352. https://doi.org/10.2527/2002.80123347x

32. Molkentin, J. (1999): Bioactive lipids naturally occurring in bovine milk. Nahrung 43 (3), 185-189. https://doi.org/10.1002/(sici)15213803(19990601)43:3<185::aid-food185>3.0.co;2-v

33. Ogawa, J., Kishino, S., Ando, A., Sugimoto, S., Mihara, K., Shimizu, S. (2005): Production of conjugated fatty acids by lactic acid bacteria. Journal of Bioscience and Bioengineering 100 (4), 355-364. https://doi.org/10.1263/jbb.100.355

34. Park, Y. (2009): Conjugated linoleic acid (CLA): Good or bad trans fat? Journal of Food Composition and Analysis 22S, S4-S12. https://doi.org/10.1016/j.jfca.2008.12.002

35. Park, Y.W., Juárez, M., Ramos, M., Haenlein, G.F.W. (2007): Physico-chemical characteristics of goat and sheep milk. Small Ruminant Research 68, 88-113. https://doi.org/10.1016/j.smallrumres.2006.09.013

36. Parodi, P.W. (2003): Anti-cancer agents in milkfat. Australian Journal of Dairy Technology 58 (2), 114-118.

37. Paszczyk, B., Brandt, W. (2016): Content of cis9trans 11 C18:2 (CLA) acid in fresh and stored kefirs. Towaroznawcze Problemy Jakości. Polish Journal of Commodity Science 3 (48), 108-114. https://doi.org/10.15193/zntj/2014/92/041-051

38. Paszczyk, B., Brandt, W., Łuczyńska, J. (2016): Content of conjugated linoleic acid (CLA) and trans isomers of C18:1 and C18:2 acids in fresh and stored fermented milks produced with selected starter cultures. Czech Journal of Food Science 34 (5), 391-396. https://doi.org/10.17221/358/2015-cjfs

39. Pecová, L., Samková, E., Hanuš, O., Hasoňová, L., Špička, J. (2019): Fatty acids stability in goat yoghurt. Ciência Rural, Santa Maria, 49 (7), 1-10. https://doi.org/10.1590/0103-8478cr20180803
40. Prandini, A., Sigolo, S., Tansini, G., Brogna, N., Piva G. (2007): Different level of conjugated linoleic acid (CLA) in dairy products from Italy. Journal of Food Composition and Analysis 20, 472-479. https://doi.org/10.1016/j.jfca.2007.03.001

41. Przybojewska, B., Rafalski, H. (2003): Fatty acids found in milk and human health. SCFA short chain saturated fatty acids (part 1). Przegląd Mleczarski 4, 148-151.

42. Rafiq, S., Huma, N., Pasha, I., Sameen, A., Mukhtar1, O., Khan, M.I. (2016): Chemical composition, nitrogen fractions and amino acids profile of milk from different animal species. Asian-Australasian Journal of Animal Sciences 29 (7), 1022-1028. https://doi.org/10.5713/ajas.15.0452

43. Salamon, R.V., Casapó-Kiss Zs., Lóki K., Csapó J. (2009a): Changes in fatty acid composition and conjugated linoleic acid contents of sour dairy products caused by pure cultures. Acta Universitatis Sapientiae Alimentaria 2 (2), 276-286. https://doi.org/10.1515/ausal-2015-0001

44. Salamon, R.V., Lóki, K., Varga-Visi, E., Mándoki, Z., Csapó, J. (2009b): Increase of conjugated linoleic acid content of dairy products by adding sunflower oil. Krmiva 51 (2), 99-103.

45. Santos Júnior, O.O., Pedrão, M.R., Dias, L.F., Paula, L.N., Coró, F.A.G., Nilson, Evelazio De Souza (2012): Fatty acid content of bovine milkfat from raw milk to yoghurt. American Journal of Applied Sciences 9 (8), 1300-1306. https://doi.org/10.3844/ajassp.2012.1300.1306

46. Seçkin, A.K., Gursoy, O., Kinik, O., Akbulut, N. (2005): Conjugated linoleic acid (CLA) concentration, fatty acid composition and cholesterol content of some Turkish dairy products. LWT 38, 909-915. https://doi.org/10.1016/j.lwt.2004.09.011

47. Serafeimidou, A., Zlatanos, S., Kritikos, G., Tourianis, A. (2013): Change of fatty acid profile, including conjugated linoleic acid (CLA) content, during refrigerated storage of yogurt made of cow and sheep milk. Journal of Food Composition and Analysis 31, 24-30. https://doi.org/10.1016/j.jfca.2013.02.011

48. Serafeimidou, A., Zlatanos, S., Laskaridis, K., Sagredos, A. (2012): Chemical characteristics, fatty acid composition and conjugated linoleic acid (CLA) content of traditional Greek yogurts. Food Chemistry 134, 1839-1846. https://doi.org/10.1016/j.foodchem.2012.03.102

49. Shantha, N.C., Ram, L.N., O'Leary, J., Hicks, C.L., Decker, E.A. (1995): Conjugated linoleic acid concentrations in dairy products as affected by processing and storage. Journal of Food Science 60 (4), 695-697. https://doi.org/10.1111/j.1365-2621.1995.tb06208.x

50. Sieber, R., Collomb, M., Aeschlimann, A., Jelen, P., Eyer, H. (2004): Impact of microbial cultures on conjugated linoleic acid in dairy products - a review. International Dairy Journal 14, 1-15. https://doi.org/10.1016/s0958-6946(03)00151-1

51. Sokoła-Wysoczańska, E., Wysoczański, T., Wagner, J., Czyż, K., Bodkowski, R., Lochyński, S., Patkowska-Sokoła, B. (2018): Polyunsaturated fatty acids and their potential therapeutic role in cardiovascular system disorders - A review. Nutrients 10, 1-21. https://doi.org/10.3390/nu10101561 
52. STATISTICA version 13.1 software, Kraków, Poland.

53. Wahrburg, C. (2004): What are the health effects of fat? European Journal of Nutrition (Suppel1) 43, I/6-1/11.

54. Williams, Ch. M. (2000): Dietary fatty acids and human health. Annales De Zootechnie 49, 165-180. https://doi.org/10.1051/animres:2000116

55. Xu, S., Boylston, T.D., Glatz, B.A. (2006): Effect of inoculation level of Lactobacillus rhamnosus and yogurt cultures on conjugated linoleic acid content and quality attributes of fermented milk products. Journal of Food Science 71 (4), C275-C280. https://doi.org/10.1111/j.1750-3841.2006.00010.x

56. Yang, B., Chen, H., Stanton, C., Ross, R.P., Zhang, H., Chen, Y.Q., Chen, W. (2015): Review of the roles of conjugated linoleic acid in health and disease. Journal of Functional Foods 15, 314-325. https://doi.org/10.1016/j.jff.2015.03.050

57. Yang, B., Gao, H., Stanton, C., Ross, R.P., Zhang, H., Chen, Y.Q., Chen, H., Chen, W. (2017): Bacterial conjugated linoleic acid production and their applications. Progress in Lipid Research 68, 26-36.

https://doi.org/10.1016/j.plipres.2017.09.002
58. Yang, L. Leung, L.K, Huang, Y., Chen, Z.Y. (2000): Oxidative stability of conjugated linoleic acid isomers. Journal of Agricultural and Food Chemistry 48, 3072-3076. https://doi.org/10.1021/jf0003404

59. Yue, J., Zheng Y., Liu Z., Deng, Y. (2016): Effects of microfiltration and storage time on cholesterol, cis-9, trans-11 and trans-10, cis-12 conjugated linoleic acid levels, and fatty acid compositions in pasteurized milk. International Journal of Food Properties, 19, 13-24. https://doi.org/10.1080/10942912.2015.1019627

60. Żegarska, Z., Paszczyk, B., Rafałowski, R., Borejszo, Z. (2006): Annual changes in the content of unsaturated fatty acids with 18 carbon atoms, including cis9trans 11 C18:2 (CLA) acid, in milk fat. Polish Journal of Food and Nutrition Sciences 15/56 (4), 409-414. https://doi.org/10.1111/j.1745-4522.2005.00022.x

61. Zunong, M., Hanada, M., Aibibula, Y., Okamato, M., Tanaka, K. (2008): Variations in conjugated linoleic acid concentrations in cow's milk, depending on feeding systems in different seasons. Asian-Australasian Journal of Animal Sciences 21 (10), 1466-1472. https://doi.org/10.5713/ajas.2008.80148 